\title{
THE EFFECT OF SOIL WATER CONTENT AND GAMAL BOKASHI ON VEGETATIVE GROWTH OF SWEET CORN (ZEA MAYS SACCARATA)
}

\author{
Nur Afifah Usman ${ }^{1)}$, Anthon Monde ${ }^{2)}$, Uswah Hasanah ${ }^{2)}$ \\ ${ }^{1)}$ Program of Agrotechnology, Faculty of Agriculture, University of Tadulako, Palu \\ ${ }^{2)}$ Faculty of Agriculture, University of Tadulako, Palu Jl. Soekarno-Hatta Km 9, Tondo-Palu 94118, Sulawesi Tengah \\ Telp.0451-429738, E-mail :nurafifagrotek@gmail.com
}

\begin{abstract}
This research aimed to get the moisture content and dose of bokashi gamal accordance with the vegetative growth of the sweet corn plant (Zea mays saccarata) and the benefit of this study was to provide the information on the effects of agriculture on groundwater levels and bokashi gamal to plants. The research design using factorial completely randomized design. The first factor bokashi gliricidia with 3 levels of treatment was without bokashi gamal (B0), bokashi gamal 20 t.ha ${ }^{-1}$ (B20), and bokashi gamal 40 t.ha $^{-1}$ (B40). The second factor levels with 3 levels of water treatments, namely, water content $50 \%$ field capacity (K50), the water content of $75 \%$ field capacity (K75), and water content $100 \%$ of field capacity (K100). Treatment was repeated three times to obtain 27 experimental units. Data analyzed by analysis of variance according to the design used and conducted a further test using Honestly Significant Difference (HSD). The results showed the interaction between water content and Bokashi Gamal significantly affected the vegetative growth of the plants sweet corn. The water content of 50-75\% and gamal bokashi 20-40 t.ha ${ }^{-1}$ gave the best to plant vegetative growth of sweet corn.
\end{abstract}

Keywords: Bokashi Gamal, Sweet Corn, Water Content.

\section{INTRODUCTION}

Sweet corn (Zea mays saccharata) is a vegetable commodity in the form of cob that is consumed in a state of youth so that the sugar content does not decrease. Sweet corn production in Indonesia is low. The demand for sweet corn from year to year is mainly for big cities like Jakarta, Bandung, and Surabaya which reached 3-8 t days-1 with demand growth rate of about $20-30 \%$ per year (Ichwan, 2007). Along with the increasing demand for sweet corn, the production of sweet corn should be improved. The obstacle, however, is most of Indonesia's corn cultivation area is dry land. The main problems of corn planting in dry land are water demand depends entirely on rainfall, variation in soil fertility and erosion which result in decreased soil fertility. In addition, other problems in dry land are soil $\mathrm{pH}$ and low organic matter content (Aria, 2009).

Corn crops can grow well in almost all places and soil types, but these plants will grow better on loose soils and rich in humus. Dense soil and strong water retention are not good for corn plant growth because root growth is imperfect, at a neutral $\mathrm{pH}$, nutrients needed by corn plants are widely available in the soil (Soeprapto, 1992). The availability of groundwater is affected by the amount of rainfall or irrigation, the ability of soil to retain water, the level of evapotranspiration, the height of the groundwater, the soil organic matter, the chemical compound or the salt content, and the depth of the soil solum or soil layer. The humidity of the transition between the rising phase and the increasing clay content is higher in the clay than in the sand(Madjid, 2009). 
Nutrient and water requirements are relatively high to support the rate of plant growth. The sweet corn plant is very sensitive to drought stress and nutrient deficiency because it is very influential on the growth and development of cob. If the water requirement is not met then the plant growth will be hampered, because the water dissolves nutrients and helps the metabolism process in corn plants (Dickert, 2001). Sweet corn needs water for growth of 300$660 \mathrm{~mm}$ each month in its growth phase (Harisand Veronica, 2005).

The availability of water in plants can be increased by the provision of sufficient artificial fertilizers to increase root growth, plant density and to protect from weeds and pest attacks. Artificial fertilizer commonly used in the form of bokashi. Bokashi is one type of organic fertilizer which is the result of fermentation or decomposition of organic materials such as plants, animals or organic waste and is an alternative fertilizer as a substitute for inorganic fertilizer to cope with the growing demand for fertilizer, and more difficult to obtain in sufficient quantities and continuously (Atekan and Surahman, 2004).

Gamal plant (Gliricidia sepium) can be used as one source of bokashi material. This plant is widely grown as a living fence, fodder and fuelwood needs and many benefits as a source of easily decomposed organic materials (Atekan and Surahman, 2004). Organic matter can act as a "binder" of primary granules into secondary soil grains in the formation of a solid aggregate. This situation has great influence on porosity, soil aeration, and soil temperature (Tahir, 2008).

The purpose of bokashi application is to increase the content of organic matter and soil nutrients in the soil, which result in physical, chemical, and soil biological improvements, which ultimately result in increased soil productivity and soil resistance to erosion. Ibrahim (1987) stated that Gamal leaves contain $3.15 \%$ of $\mathrm{N}$, $0.22 \%$ of $\mathrm{P}, 2.65 \%$ of $\mathrm{K}, 1.35 \%$ of $\mathrm{Ca}$, and
$0.41 \%$ of $\mathrm{Mg}$. To obtain good characteristic of organic fertilizer, the duration of decomposition of Gamal leaves besides decomposition technique should be better calculated. As a follow-up to overcome this problem, experiments have been conducted on the length of composting of Gamal leaves and their effects on plant growth.

Based on the above description, it is deemed necessary to research about "The Effect Of Soil Water Content And Gamal Bokashi On Vegetative Growth Of Sweet Corn (Zea mays Saccarata)"

Puprose and Benefit. This research was conducted with the aim to get water content and dosage of bokashi from Gamal leaves which suitable with vegetative growth of sweet corn plant (Zea mays saccarata). The benefit of this research is to provide information in the agricultural sector about the proper groundwater content and bokashi from gamal for sweet corn growth.

\section{RESEARCH METHODS}

Location and Time. This research was conducted from March to April 2016. This research was conducted at Greenhouse of Agriculture Faculty, University of Tadulako. Soil analysis was conducted at Soil Science Laboratory, Faculty of Agriculture, Tadulako University, Palu.

Tools and Materials. The tools used in this research were $1000 \mathrm{ml}$ measuring cup, 100 $\mathrm{ml}$ measuring cup, $2 \mathrm{~mm}$ sieve, scop, sample ring, tarpaulin, bucket, label paper, analytical scales, stirrer, sack, and stationery. While the materials used were land taken from Sidera Village, Gamal leaves, bran, manure, water, sugar, EM4, and sweet corn seed.

Research Design . This research was prepared by using Completely Randomized Design (RAL) of factorial pattern which was repeated 3 times with treatment consisting of:

The first factor is bokashi from Gamal leaves with 3 levels of treatment: 
$\mathrm{B}_{0}=$ Without bokashi fertilizer

$\mathrm{B}_{20}=$ Bokashi Gamal $\left(20\right.$ t.ha $\left.^{-1}\right)$ which is equal to166.67 g.pot ${ }^{-1}$

$\mathrm{B}_{40}=$ Bokashi gamal $\left(40\right.$ t.ha $\left.^{-1}\right)$ which is equal to333.33 g.pot ${ }^{-1}$

The second factor is water content with 3 levels of treatment:

$\mathrm{K}_{50}=$ Water content (50\% of Field Capacity)

$\mathrm{K}_{75}=$ Water content (75\% of Field Capacity)

$\mathrm{K}_{100}=$ Water content (100\% of Field Capacity)

Each treatment was repeated 3 times to obtain 27 units of the experiment. The observed variables used in this study were the number of leaves, the fresh weight of the plant, the dry weight of the plant, the fresh weight of the roots, the dry weight of the roots and the weight of the soil content.

Research Implementation. In this study the first step was to sift the soil and separated from other garbage or dirt after that the clean soil then weighed $10 \mathrm{~kg}$ weight. The weighed soil was then fed into the already-available bucket and then mixed with bokashi from gamal leaves with the conversion of 20 t.ha $^{-1}\left(166.67 \mathrm{~g} \mathrm{pot}^{-1}\right), 40$ t.ha ${ }^{-1}$ (333.33 g pot $\left.^{-1}\right)$ and without bokashi, bokashi from gamal leaves that in use was bokashi from the mature leaf of gamal. Planting was performed by using 3 seeds per pot. After a week, thinning was performed by separating one plant per pot. The initial watering was performed up to the field capacity. After the planting was performed then watered with a different water volume of $50 \%$ of field capacity (2.39 L), $75 \%(3.58 \mathrm{~L})$ and $100 \%(4.78 \mathrm{~L})$. The water that has been given was maintained every day with weighing. Watering was performed every day to maintain the water content according to the treatment.

Data Analysis. The results of the study were analyzed by using variance analysis. If the analysis of variance indicated that the existence of the significant effect then test continued by using Honestly Significant Difference (HSD) at 5\% level or at $95 \%$ confidence level, but if the results of variance did not have significant effect hence did not do further test.

\section{RESULTS AND DISCUSSION}

The Number of Leaves. Based on the result of variance analysis, there was interaction of treatment between water content and bokashi from gamal leaves on the increase of leaf number.

The result of leaf number HSD test showed that on treatment of 40 t.ha $^{-1}$ bokashi and water content of $75 \%$, treatment of 40 t.ha $^{-1}$ bokashi and water content of $50 \%$, treatment of $20 \mathrm{t}^{-h^{-1}}$ bokashi and water content of $75 \%$ and treatment of 20 t.ha $^{-1}$ bokashi and water content of $50 \%$ gave the highest average number of leaves but not significantly different from one another. However, significantly different results were the treatment without bokashi and water content of $50 \%$ and 20 t.ha $^{-1}$ bokashi and water content of $100 \%$ and followed by treatment of 20 t.ha $^{-1}$ bokashi and $100 \%$ water content and the treatment without bokashi and water content of $75 \%$ which was not significantly different, whereas in treatment of 40 t.ha $^{-1}$ bokashi and $100 \%$ water content was not significantly different with the treatment without bokashi and water content of $75 \%$, followed by treatment without bokashi and $100 \%$ water

Table 1. Average Number Of Leaves Of Sweet Corn Plants On The Treatment Of Water Content And Various Doses Of Bokashi Gamal.

\begin{tabular}{ccc}
\hline Treatment & Average & HSD 1\% \\
\hline B0K100 & $11.67^{\mathrm{a}}$ & \\
B40K100 & $13.00^{\mathrm{b}}$ & \\
B0K75 & $13.67^{\mathrm{bc}}$ & \\
B20K100 & $14.33^{\mathrm{cd}}$ & 1.10 \\
B0K50 & $15.33^{\mathrm{d}}$ & \\
B20K50 & $17.00^{\mathrm{e}}$ & \\
B20K75 & $17.00^{\mathrm{e}}$ & \\
B40K50 & $17.00^{\mathrm{e}}$ & \\
B40K75 & $17.33^{\mathrm{e}}$ & \\
\hline
\end{tabular}

Description : The numbers followed by the same letter in the same column showed no significant difference at the HSD test level of $1 \%$ content with lowest number of leaves. 
This shows that the treatment of water and bokashi with different doses would affect the increase in the number of leaves. Bokashi gamal contains nutrients that are useful for the growth of sweet corn crops. According Latarang and Syakur (2006) who stated that the formation of the number of leaves is determined by the number and size of cells, is also influenced by the nutrients absorbed by the roots to serve as food.

The availability of water plays an important role in plant growth, the availability of sufficient water will be utilized by plants to grow maximally. Similarly, if there is water stress on the plants that will give the impact of slow growth or stunted so that the plant grows dwarf and has a small amount of leaves. In accordance with the statement of Gardner (1991) who stated that at the stage of vegetative growth, drought stress can reduce the growth of plant height, leaf formation, and the increase of leaf area.

Fresh Weight of Plant. Based on result of data analysis on sweet corn plant growth there was interaction between water treatment and bokashi gamal on fresh weight of plant.

Table 2. Average Fresh Weight Of Sweet Corn Plants On The Treatment Of Water Content And Various Doses Of Bokashi Gamal.

\begin{tabular}{ccc}
\hline Treatment & Average & HSD 1\% \\
\hline B0K100 & $14.22^{\mathrm{a}}$ & \\
B40K100 & $31.52^{\mathrm{ab}}$ & \\
B0K75 & $38.47^{\mathrm{ab}}$ & \\
B20K100 & $77.77^{\mathrm{bc}}$ & 56.22 \\
B0K50 & $120.27^{\mathrm{c}}$ & \\
B20K75 & $221.58^{\mathrm{d}}$ & \\
B40K75 & $307.33^{\mathrm{e}}$ & \\
B40K50 & $312.47^{\mathrm{e}}$ & \\
B20K50 & $323.60^{\mathrm{e}}$ & \\
\hline
\end{tabular}

Description : The numbers followed by the same letter in the same column showed no significant difference at the HSD test level of $1 \%$
The result of leaf number HSD test showed that on treatment of 40 t.ha- 1 bokashi and water content of $75 \%$, treatment of 40 t.ha $^{-1}$ bokashi and water content of $50 \%$, and treatment of 20 t.ha $^{-1}$ bokashi and water content of $50 \%$ gave the highest average plant fresh weight but not significantly different from one another. However, significantly different results were the treatment of $20 \mathrm{t}^{-h a^{-1}}$ bokashi and water content of $75 \%$ and without bokashi and water content of $50 \%$, followed by treatment of 20 t.ha $^{-1}$ bokashi and $100 \%$ water content and treatment without bokashi and water content of $75 \%$ which was not significantly different, whereas in

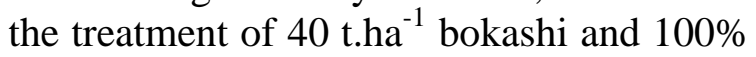
water content was not significantly different with treatment without bokashi and water content of $75 \%$, followed by without bokashi treatment and $100 \%$ water content with average amount of the lowest fresh weight of the plant.

This indicated that bokashi treatment and water treatment affect the fresh weight of sweet corn plants because the wet weight or fresh weight of a plant is highly volatile, which depend on the water content it contains. When the plant tissue dries it will lose its fresh weight. Lack of water will disrupt the chemical balance in the soil which results in a lack of photosynthesis or all physiological processes will run abnormally if this condition goes on, then the results are seen, such as dwarf plants, wilts, low production, low quality, etc (Kimball, 1989).

Dry Weight of Plant.Based on the results of the variance analysis on the growth of sweet corn plants there was an interaction between water treatment and bokashi gamal on the fresh weight of plants.

The result of HSD dry weight test showed that the highest average fresh weight of plants was found in treatment of 20 t.ha $^{-1}$ and $50 \%$ water content and 20 t.ha ${ }^{-}$ ${ }^{1}$ bokashi and $75 \%$ water content were not significantly different, while treatment of 40 t.ha ${ }^{-1}$ bokashi and 50\% water content and 40 
t.ha ${ }^{-1}$ bokashi and $75 \%$ moisture content were not significantly different from treatment. However, significantly different results were the treatment without bokashi and water content of $50 \%$ and 20 t.ha $^{-1}$ bokashi and $100 \%$ water content, followed by treatment without bokashi and water content of $75 \%$ and 40 t.ha $^{-1}$ bokashi and water content of $100 \%$ which were not significantly different. However, there was significantly different from the treatment without bokashi and $100 \%$ water content that had the lowest average dry plant weight.

This shows the effect of bokashi and water treatment on the dry weight of the plant. Organic fertilizer such as bokashi contains nutrients needed by plants, nutrients used by plants to perform photosynthesis so plants can grow and develop, so the application of bokashi gamal is very beneficial for sweet corn plants because it contains many $\mathrm{N}$ elements that can increase the growth so that it will increase dry weight of sweet corn plant. Nyakpa et al (1988) stated that nitrogen is the main composition of dry weight of young plants compared with old plants, $\mathrm{N}$ elements must be available in plants before the formation of new cells, because it will not take place without nitrogen.

Table 3. Average dry weight of sweet corn plants on the treatment of water content and various doses of bokashi gamal.

\begin{tabular}{ccc}
\hline Treatment & Average & HSD 1\% \\
\hline B0K100 & $5.35^{\mathrm{a}}$ & \\
B40K100 & $10.80^{\mathrm{ab}}$ & \\
B0K75 & $19.73^{\mathrm{ab}}$ & \\
B20K100 & $30.32^{\mathrm{b}}$ & 23.12 \\
B0K50 & $42.23^{\mathrm{b}}$ & \\
B40K75 & $106.73^{\mathrm{c}}$ & \\
B40K50 & $124.52^{\mathrm{c}}$ & \\
B20K75 & $129.17^{\mathrm{cd}}$ & \\
B20K50 & $148.70^{\mathrm{d}}$ & \\
\hline
\end{tabular}

Description : The numbers followed by the same letter in the same column showed no significant difference at the HSD test level of $1 \%$
Table 4. Average Fresh Weight Of Sweet Corn Plants Roots On Water Treatment And Various Doses Of Bokashi Gamal.

\begin{tabular}{ccc}
\hline Treatment & Average & HSD 1\% \\
\hline B0K100 & $3.37^{\mathrm{a}}$ & \\
B40K100 & $8.20^{\mathrm{ab}}$ & \\
B0K75 & $9.63^{\mathrm{ab}}$ & \\
B20K100 & $15.23^{\mathrm{ab}}$ & 12.76 \\
B0K50 & $17.57^{\mathrm{b}}$ & \\
B20K75 & $41.63^{\mathrm{c}}$ & \\
B40K50 & $54.47^{\mathrm{d}}$ & \\
B20K50 & $54.60^{\mathrm{d}}$ & \\
B40K75 & $75.80^{\mathrm{e}}$ & \\
\hline
\end{tabular}

Description : The numbers followed by the same letter in the same column showed no significant difference at the HSD test level of $1 \%$

The application of $100 \%$ water of field capacity was not significantly different with $75 \%$ of field capacity. This is because water is the photosynthesis material and photosynthesis results are still distributed on plant organ growth (stems, roots, leaves) so that hoarding of photosynthate was still optimal, subsequent observations had no effect because the accumulation of dry materialsstill focused on the cob. In accordance with the statement of Jasminarni (2008) that the resulting photosynthate is mostly transferred in the generative phase that can stimulate the formation of sweet corn cobs.

Fresh Weight of Roots. Based on the result of variance analysis, there was interaction between treatment of water content and bokashi from gamal leaf to fresh weight of roots.

The result of test by using HSD at $1 \%$ indicated that in treatment of 40 t.ha $^{-1}$ bokashi and water content of $75 \%$ gave the highest fresh weight of sweet corn plant roots which was significantly different with treatment of 40 t.ha $^{-1}$ bokashi and water content of $50 \%$ and 20 t.ha-1 and 50\% water content, followed by treatment of 20 t.ha $^{-1}$ bokashi and $75 \%$ water content. However, there were significantly different 
results of bokashi treatment and 50\% water content, but not significantly different with 20 t.ha $^{-1}$ bokashi and $100 \%$ water content, without bokashi and water content of $75 \%$ and 40 t.ha $^{-1}$ bokashi and $100 \%$ water content, followed by treatment without bokashi and $100 \%$ water content which had the lowest average fresh root weight.

The application of bokashi gamal and water affects plant growth and root development in sweet corn plants. Bokashi and water content provide nutrients to support the formation of branches in sweet corn roots thereby increasing the fresh weight of the roots. The results showed that 40 t.ha-1 bokashi and $75 \%$ water gave the good result because it yielded the highest fresh weight of root compared with other treatment. Djohana (1989) stated that the application of fertilizer must be in the right amount to obtain optimal fertilization result.

Dry Weight of Roots. Based on the results of variance analysis on sweet corn plant growth showed interaction between water treatment and bokashi gamal on dry weight of roots.

The result of $1 \%$ HSD test showed that the highest dry weight of plant roots was found in treatment of 20 t.ha-1 bokashi and $75 \%$ water content that was significantly different from 20 t.ha- 1 and $75 \%$ water content, followed by treatment of 40 t.ha-1 bokashi and water content of $50 \%$, treatment of 20 t.ha-1 bokashi and water content of $50 \%$, and treatment without bokashi and $50 \%$ water were significantly different but treatment of 20 t.ha-1 bokashi and water content of $100 \%$ and without bokashi and $75 \%$ water content were not significantly different with treatment without bokashi and 50\% water content. Then followed by treatment of 40 t.ha-1 bokashi and $100 \%$ water content and without bokashi and $100 \%$ water content which were not significantly different and had the lowest average dry root weight.

This shows that the treatment without bokashi and $100 \%$ water content resulted in the decrease of dry weight of sweet corn plant roots. Root development will work well if supported by good soil structure so that water absorption and nutrients can meet the needs of plants for plant growth process. This is in accordance with the opinion of Suwardjono (2004), which stated that good soil structure makes roots well developed so that the broader area of nutrients uptake. The smooth process of nutrient uptake by plants depending on the groundwater supply associated with the capacity to retain water by the soil may affect the dry weight of the roots.

Table 5. Average Dry Weight Of Sweet Corn Plants On Water Treatment And Various Doses Of Bokashi Gamal.

\begin{tabular}{ccc}
\hline Treatment & Average & HSD 1\% \\
\hline B0K100 & $2.33^{\mathrm{a}}$ & \\
B40K100 & $3.93^{\mathrm{ab}}$ & \\
B0K75 & $6.73^{\mathrm{bc}}$ & \\
B20K100 & $6.90^{\mathrm{bc}}$ & \\
B0K50 & $9.10^{\mathrm{c}}$ & 3.34 \\
B20K50 & $13.30^{\mathrm{d}}$ & \\
B40K50 & $18.57^{\mathrm{e}}$ & \\
B20K75 & $22.47^{\mathrm{f}}$ & \\
B40K75 & $27.35^{\mathrm{g}}$ & \\
\hline
\end{tabular}

Description : The numbers followed by the same letter in the same column showed no significant difference at the HSD test level of $1 \%$.

Table 6. Average Soil Content Weight Of Sweet Corn Plant In Water Treatment And Various Doses Of Bokashi Gamal.

\begin{tabular}{ccc}
\hline Treatment & Average & HSD 1\% \\
\hline B40K50 & $1.40^{\mathrm{a}}$ & \\
B40K75 & $1.45^{\mathrm{ab}}$ & \\
B40K100 & $1.46^{\mathrm{ab}}$ & \\
B20K75 & $1.52^{\mathrm{abc}}$ & 0.14 \\
B20K100 & $1.56^{\mathrm{bc}}$ & \\
B20K50 & $1.57^{\mathrm{c}}$ & \\
B0K50 & $1.61^{\mathrm{cd}}$ & \\
B0K75 & $1.77^{\mathrm{de}}$ & \\
B0K100 & $1.90^{\mathrm{e}}$ & \\
\hline
\end{tabular}

Description : The numbers followed by the same letter in the same column showed no significant difference at the HSD test level of $1 \%$. 
Soil Content Weight. Based on the result of variance analysis, there was interaction between treatment of water content and bokashi from gamal leaf to the weight of soil contents.

The results of test by using HSD at $1 \%$ indicated that in treatment without bokashi and $100 \%$ water content resulted in the highest weight of sweet corn soil content that was the same or not significantly different with treatment without bokashi and water content of $75 \%$, followed by treatment without bokashi and water content of $50 \%$, treatment of 20 t.ha-1 bokashi and $50 \%$ water content, and 20 t.ha-1 bokashi and $100 \%$ water content which were not significantly different and followed by treatment of 20 t.ha- 1 bokashi and water content of $75 \%, 40$ t.ha- 1 bokashi and $100 \%$ water content, and 40 t.ha-1 bokashi and water content of $75 \%$ which were not significantly different. Treatment of 40 t.ha- 1 bokashi and 50\% water content had the lowest average weight of the soil contents.

This shows the treatment of bokashi and water application affected the weight of the soil content. The weight of the soil content is a clue to the density of the soil, the denser a soil the higher the weight of the soil content (Bulk density), which means it is increasingly difficult to continue the water or penetrate the roots of the plant. The value of the weight of the content can be influenced by several factors, including soil processing, organic matter, compaction of agricultural equipment, texture, structure, and soil water content. The weight of the soil content is important to calculate the need for fertilizer or water for each hectare of land, based on the weight of the soil, and for the growth of the root (Hanafiah, 2010). Application of organic matter on soil can improve soil aeration and drainage, retain water content in the soil, and decrease soil content weight so that soil consistency is more friable which will allow roots to grow and develop better. This is in line with the statement of Wahyudi (2009), that the soil processing can improve the development of plant roots so that it can absorb nutrients well so as to increase plant growth.

\section{CONCLUSION AND SUGGESTION}

\section{Conclusion}

Based on the results of research conducted, it can be concluded as follows:

1. The interaction between treatment of water content and bokashi gamal gave a real effect on vegetative growth of sweet corn.

2. Water content of $50-75 \%$ and dose of 20-40 t.ha-1 bokashi provided the best growth on the number of sweet corn leaves, fresh weight of the plant, dry weight of plant, fresh weight of roots, and dry weight of roots.

3. Maintain $100 \%$ water content and treatment without bokashi gave the highest weight of soil contents.

\section{Suggestion}

It is recommended to research the use of bokashi gamal with different doses on sweet corn crops. As well as analyzing the maturity of bokashi gamal to be used in further research.

\section{REFERENCES}

Aria, B. 2009. Pengaruh Dosis Pupuk Kandang dan Frekuensi Pemberian Pupuk Urea terhadap Pertumbuhan dan Produksi Jagung (Zea mays L.) di Lahan Kering. J.Agritrop, 26 (4): 21.

Atekan dan Surahman., 2004. Peranan Bahan Organik Asal Daun Gamal (Gliricidia sepium) Sebagai Amelioran Aluminium pada Tanah Ultisol. Balai Pengkajian Teknologi Pertanian Nusa Tenggara Barat. 
Dickert and W.F. Tracy. 2001. Irrigation and Sugar in Sweet Corn. J.of Quensland Agric. 106: 218 -230 .

Djohana, 1989. Pupuk dan Pemupukan. Simpleex. Jakarta.

Gardner P. 1991. Fisiologi Tanaman Budidaya. Jakarta. Universitas Indonesia.

Hanafiah, K. A, 2010. Dasar-Dasar Ilmu Tanah. Raja Grafindo Persada. Jakarta.

Haris, A dan Veronica Crestiani. 2005. Studi Pemupukan Kalium terhadap Pertumbuhan dan Hasil Jagung Manis (Zea mays saccharata Sturt) Varietas Super Bee. J. Agroland. 17(3): 10.

Ibrahim, 1987. Dasar-Dasar Ilmu Tanah. Badan Kerjasama Perguruan Tinggi Negeri Indonesia Bagian Timur.

Ichwan, B. 2007. Pengaruh Efek Mikroorganisme-4 (EM-4) dan Kompos terhadap Pertumbuhan Jagung Manis (Zea mays saccharata) pada tanah Entisol. J. Agron. 11(2): 32.

Jasminarni, 2008. Pengaruh Jumlah Pemberian Air terhadap Pertumbuhan dan Hasil Selada (Lactuca sativa L.) di Polibag. J. Agron.12(1): 1-4.

Kimball, J.W. 1989. Biologi. Erlangga. Jakarta.

Latarang, P. dan A. Syakur., 2006. Pertumbuhan dan Hasil Bawang Merah (Allium ascalanicum L) pada Berbagai Dosis Pupuk Kandang. J. Agroland.

Madjid, A. 2009. Dasar-Dasar Ilmu Tanah. Bahan Ajar Online. Fakultas Pertanian Unsri Dan Program Studi Ilmu Tanaman, Program Magister (S2), Program Pascasarjana, Universitas Sriwijaya.http://dasar-dasar ilmutanah. blogspot.com, Diakses Tanggal 21 September 2015. Palu.

Nyakpa, Y. A. M. Lubis, M. A. Pulung, A. G. Amrah, A. Munawar, G. B. Hong dan N. Hakim. 1988. Kesuburan Tanah, Universitas Lampung-Press. Lampung.

Soeprapto, H., 1992. Budidaya Jagung. Penerbit Swadaya. Jakarta.

Suwardjono. 2004. Pengaruh Beberapa Jenis Pupuk Kandang terhadap Pertumbuhan dan Produksi Kacang Tanah. Http// www.ut.ac.id/jmst/jurnal/Suwardjono/ pengaruh htm. Diakses 19 Desember 2016.

Tahir, M. H., 2008. Pengaruh Pemberian Pupuk Hijau Gamal Terhadap Perubahan Beberapa Sifat Fisik Entisol Salin Lembah Palu.Skripsi Fakultas Pertanian, Universitas Tadulako, Palu.

Wahyudi, I. 2009. Manfaat Bahan Organik Terhadap Peningkatan Persediaan Fosfor dan Penurunan Toksisitas Aluminium di Ultisol. Desertasi Program Doktor.Universitas Brawijaya. Malang. 